\title{
Canine chondrodystrophic intervertebral disc disease (Hansen type I disc disease)
}

\author{
Clare Rusbridge $e^{1,2}$ \\ From Musculoskeletal Health in the 21st Century \\ Guildford, UK. 30 June - 1 July 2015
}

Intervertebral disc disease (IVDD) is the most common spinal disease in dogs. Chondrodystrophic dogs, which have disproportionably short and curved limbs, are predisposed to Hansen type I IVDD and of these the miniature Dachshund is over represented [1,2], is more likely to be presented at an earlier age [3] and is at greater risk of a severe spinal cord injury [4]. The tendency for IVDD in Dachshunds is inherited [5,6] and a major locus on chromosome 12 harbours genetic variations affecting the development of intervertebral disc calcification [7]. Hansen type I disc degeneration is thought to occur because of loss of notochordal cells which produce proteoglycans which "hold water" in the disc. Chondrodystrophic dogs have a primary deficiency of notochordal cells, a study found that large notochordal cells in the nucleus pulposus of chondrodystrophoid dogs formed $13 \%$ of the cell population in young dogs and fell to $0.4 \%$ in adults, whereas they were the predominant cell type in the nonchondrodystrophoid dogs at all ages [8]. Thus chondrodystrophoid dogs suffer early degenerative changes in the disc and a concomitant reduction in proteoglycan content, increased collagen, and loss of water content making the discs likely to herniate [8]. Certain lifestyle factors may increase or decrease risk of IVDD and this is currently under investigation. There is a suggestion that exercise (including stair climbing) reduces the incidence of disc calcification [9]. By contrast it has been hypothesized that obesity/lack of postural muscle strength may increase risk. Dachshunds with intervertebral disc extrusion had significantly smaller cross sectional area and greater fat infiltration in the epaxial muscles (muscles which lie dorsal to the horizontal septum of the vertebrae which mobilize and globally stabilize the trunk [10]) compared to dogs presenting with fibrocartilagenous embolism (another acute

${ }^{1}$ Fitzpatrick Referrals, Halfway Lane, Eashing, Godalming, Surrey, GU7 2QQ, UK

Full list of author information is available at the end of the article onset intervertebral disc related spinal disease) [11]. In addition chondrodystrophic dogs may have increased risk of IVVD if they have a more extreme conformation e.g. Dachshunds that have a longer back and shorter limbs are more at risk [12] and breeds with a comparatively heavy head such as the Bassett Hound may be more at risk of cervical disc disease. Breeds with a tendency for kyphoscoliosis such as the French Bulldog may be more at risk of IVDD in the IVDs adjacent to a vertebral malformation $[13,14]$. This presentation details the pathogeneis, clinical presentation, diagnosis and treatment of IVDD in chondrodystrophic dogs.

\section{Authors' details}

${ }^{1}$ Fitzpatrick Referrals, Halfway Lane, Eashing, Godalming, Surrey, GU7 2QQ, UK. ${ }^{2}$ School of Veterinary Medicine, Faculty of Health \& Medical Sciences, Duke of Kent Building, University of Surrey, Guildford, Surrey, GU2 7TE, UK.

Published: 1 December 2015

\section{References}

1. Bergknut N, Egenvall A, Hagman R, Gustas P, Hazewinkel HA, Meij BP, Lagerstedt AS: Incidence of intervertebral disk degeneration-related diseases and associated mortality rates in dogs. J Am Vet Med Assoc 2012, 240(11):1300-1309.

2. Stigen $\mathrm{O}$ : Calcification of intervertebral discs in the dachshund: a radiographic study of 115 dogs at 1 and 5 years of age. Acta Vet Scand 1996, 37(3):229-237.

3. Itoh $H$, Hara $Y$, Yoshimi N, Harada $Y$, Nezu Y, Yogo T, et al: A retrospective study of intervertebral disc herniation in dogs in Japan: 297 cases. J Vet Med Sci 2008, 70(7):701-706.

4. Olby N, Levine J, Harris T, Munana K, Skeen T, Sharp N: Long-term functional outcome of dogs with severe injuries of the thoracolumbar spinal cord: 87 cases (1996-2001). J Am Vet Med Assoc 2003, 222(6):762-769.

5. Jensen VF, Christensen KA: Inheritance of disc calcification in the dachshund. J Vet Med A Physiol Pathol Clin Med 2000, 47(6):331-340.

6. Stigen O, Christensen K: Calcification of intervertebral discs in the dachshund: an estimation of heritability. Acta Vet Scand 1993, 34(4):357-361.

7. Mogensen MS, Karlskov-Mortensen P, Proschowsky HF, Lingaas F, Lappalainen A, Lohi $\mathrm{H}$, et al: Genome-wide association study in Dachshund: identification of a major locus affecting intervertebral disc calcification. J Hered 2011, 102(Suppl 1):S81-S86. 
8. Cappello R, Bird JL, Pfeiffer D, Bayliss MT, Dudhia J: Notochordal cell produce and assemble extracellular matrix in a distinct manner, which may be responsible for the maintenance of healthy nucleus pulposus. Spine (Phila Pa 1976) 2006, 31(8):873-882.

9. Jensen VF, Ersboll AK: Mechanical factors affecting the occurrence of intervertebral disc calcification in the dachshund-a population study. J Vet Med A Physiol Pathol Clin Med 2000, 47(5):283-296.

10. Schilling N, Carrier DR: Function of the epaxial muscles in walking, trotting and galloping dogs: implications for the evolution of epaxial muscle function in tetrapods. J Exp Biol 2010, 213(Pt 9):1490-1502.

11. Bostrom AF, Hielm-Bjorkman AK, Chang YM, Weller R, Davies ES:

Comparison of cross sectional area and fat infiltration of the epaxial muscles in dogs with and without spinal cord compression. Res Vet SCi 2014, 97(3):646-651.

12. Packer RM, Hendricks A, Volk HA, Shihab NK, Burn CC: How long and low can you go? Effect of conformation on the risk of thoracolumbar intervertebral disc extrusion in domestic dogs. PLoS One 2013, 8(7): e69650

13. Aikawa T, Shibata M, Asano M, Hara Y, Tagawa M, Orima H: A comparison of thoracolumbar intervertebral disc extrusion in French Bulldogs and Dachshunds and association with congenital vertebral anomalies. Vet Surg 2014, 43(3):301-307.

14. Faller K, Penderis J, Stalin C, Guevar J, Yeamans C, Gutierrez-Quintana R: The effect of kyphoscoliosis on intervertebral disc degeneration in dogs. Vet J 2014, 200(3):449-451.

doi:10.1186/1471-2474-16-S1-S11

Cite this article as: Rusbridge: Canine chondrodystrophic intervertebral disc disease (Hansen type I disc disease). BMC Musculoskeletal Disorders 2015 16(Suppl 1):S11.

\section{Submit your next manuscript to BioMed Central and take full advantage of:}

- Convenient online submission

- Thorough peer review

- No space constraints or color figure charges

- Immediate publication on acceptance

- Inclusion in PubMed, CAS, Scopus and Google Scholar

- Research which is freely available for redistribution

Submit your manuscript at www.biomedcentral.com/submit 